\title{
Preparation of Sago Bark-Derived Magnetic Adsorbent by Impregnation and Carbonation for Lead and Copper lons Removal
}

\author{
Soh Fong Lim ${ }^{1, a,{ }^{*}}$, Nur Amalina Naimah Hamidon ${ }^{1, b}$, Sukinah Abdul Karim ${ }^{1, c}$, \\ S.N. David Chua ${ }^{1, d}$ and Bee Huah Lim ${ }^{2, e}$
}

${ }^{1}$ Faculty of Engineering, Universiti Malaysia Sarawak 94300 Kota Samarahan, Sarawak, Malaysia

${ }^{2}$ Fuel Cell Institute, Universiti Kebangsaan Malaysia, 43600 UKM Bangi, Selangor, Malaysia

asflim@unimas.my, bnuramalina.naimah@gmail.com, csukiesukinah@gmail.com, dcsndavid@unimas.my, ebeehuah@ukm.edu.my

Keywords: Sago bark, heavy metal ions removal, magnetic biochar, adsorption isotherm.

\begin{abstract}
This paper presents an alternative utilisation of sago barks from the sago industry. In this study, a sago bark-derived magnetic adsorbent was developed by impregnation with ferric chloride hexahydrate $\left(\mathrm{FeCl}_{3} \mathrm{H}_{2} \mathrm{O}\right)$ and carbonisation method. The potential of the sago bark-derived magnetic adsorbent to remove lead ion $\left(\mathrm{Pb}^{2+}\right)$ and copper ion $\left(\mathrm{Cu}^{2+}\right)$ from aqueous solution was assessed in a batch system. Adsorption experiments were performed as a function of initial concentration (5.0 $15.0 \mathrm{mg} / \mathrm{L})$. The magnetic adsorbent displayed good ferromagnetic property which aids the separation of the adsorbent after the decontamination process. The magnetic adsorbent was characterised by Fourier Transform Infrared (FTIR) Spectroscopy and Scanning Electron Microscopy embedded with an Energy Dispersive X-ray Spectrometer (SEM-EDX). The FT-IR spectra analysis revealed the surface functional groups of the magnetic adsorbent are $\mathrm{C}-\mathrm{O}-\mathrm{C}, \mathrm{C}-\mathrm{OH}, \mathrm{C}-\mathrm{H},-\mathrm{C}-\mathrm{C}-\mathrm{O}, \mathrm{Fe}-\mathrm{O}$, $\mathrm{O}-\mathrm{H}$, and $\mathrm{C}-\mathrm{O}$. The maximum monolayer adsorption capacities were discovered to be 172.414 and $12500 \mathrm{mg} / \mathrm{g}$ for lead and copper ions, respectively. The batch adsorption isotherms were analysed using Langmuir, Freundlich, Jovanovic and Temkin isotherm models. The experimental data perfectly fitted with Langmuir isotherm modelling. The results indicated that the sago bark-derived magnetic adsorbent potentially to be an alternative in replacing more high-priced adsorbents for its application in heavy metal ions removal.
\end{abstract}

\section{Introduction}

Sago bark is considered as a renewable source that contains lignocellulosic material [1]. In Malaysia, the demand of sago starch has increased, and Sarawak has been known to be the biggest exporter of Sago starch in the world. Sarawak alone has contributed to an average export volume of 40,000 to 50,000 metric tons of sago starch per year [2]. Due to the increases in the volume of dried sago produce per year, the amount of sago waste also increases as every ton of dried sago starch produce will generate 0.5 tons of sago bark as waste[3]. Production of sago barks as a by-product of sago mill industries in Sarawak is more than 20,000 ton/yr [4].Current practice in managing the overabundant sago barks is by eliminating the sago barks through open and controlled burning which could either cause air pollution or furnace chimney corrosion [5]. Reference [5] pointed out that dumping the sago barks into nearby rivers is unacceptable as it could cause environmental problems, and the rivers also becoming shallow. Thus, immediate action is needed in utilising the sago barks effectively and efficiently.

Biochar is an adsorbent for the wastewater treatment process, which is used to remove various toxic pollutants [6]. Biochar has been reported to have a better adsorption capacity compared to activated carbon [7]. But, the application of biochar practically into the wastewater treatment process is quite complicated as it needs to accompany with filtration and centrifugation process after the adsorption [8]. Separation of the powdered biochar from aqueous solution is a challenge due to the particle size of the biochar. Nevertheless, because of its properties, biochar which has a massive surface area, porous structures, large pores volumes, consists of abundant functional groups, low raw material cost, and environmentally friendly, has made it a popular subject to improve in the 